\title{
PENGARUH KOMPETENSI, IKLIM ORGANISASI, DAN MOTIVASI TERHADAP PRODUKTIVITAS KERJA PEGAWAI (STUDI KASUS PADA DINAS SYARIAT ISLAM KABUPATEN BENER MERIAH)
}

\author{
Yusmika Indah ${ }^{1}$ \\ Ilmu Tata Niaga, Politeknik Negeri Lhokseumawe \\ yusmika indah@pnl.ac.id \\ Muhsin Efendi \\ Ilmu Administrasi Negara, Universitas Gajah Putih \\ muhsin85.efendi@gmail.com
}

\begin{abstract}
The purpose of this research is to know the influence : 1) Competence to productivity of employee at Dinas Syariat Islam Kabupaten Bener Meriah, 2) Organizational climate to productivity of employee at Dinas Syariat Islam Kabupaten Bener Meriah, 3) Motivation to productivity of employee at Dinas Syariat Islam Kabupaten Bener Meriah, 4) Competence, Organizational climate, and Motivation to productivity of employee at Dinas Syariat Islam Kabupaten Bener Meriah. The population is the research were all employee at Dinas Syariat Islam Kabupaten Bener Meriah as much as 44 employee and all it become sample. The sample strategy employee in this research using saturate sampling. Methods og data collection using questionnaire. Futher testing validity and reliability. Analysis techniques used is multiple linier regression. The result this research was showed that : 1) Competence have a positive and significant effect to productivity of employee at Dinas Syariat Islam Kabupaten Bener Meriah, 2) Organizational climate have a positive and significant effect to productivity of employee at Dinas Syariat Islam Kabupaten Bener Meriah, 3) Motivation have a positive and significant effect to productivity of employee at Dinas Syariat Islam Kabupaten Bener Meriah, 4) Competence, Organizational climate and Motivation have a positive and signific productivity of employee at Dinas Syariat Islam Kabupaten Bener Meriah.
\end{abstract}

Keyword : Competence, Organizational Climate, Motivation, Productivity

\section{PENDAHULUAN}

Pegawai Negeri Sipil adalah salah satu elemen yang memegang tanggung jawab dalam suatu organisasi, baik itu dalam perencanaan, pelaksanaan dan penggerak serta sekaligus bertindak sebagai pengawas dalam pembangunan bangsa ini. Mereka tersebar diberbagai departemen, lembaga tinggi, dan instansi pemerintahan dari pusat sampai kepelosok tanah air dan menjadi tulang pembangunan nasional. Pada pembangunan mendatang kewajiban aparatur untuk mewujudkan keadilan dan pemerataan dalam masyarakat lebih ditingkatkan melalui suatu birokrasi yang professional, competence and honest. Hal ini bukanlah suatu tuntutan yang berlebihan. Tuntutan yang baru dapat dirumuskan di dalam etos kerja PNS yaitu bagaimana dedikasi PNS itu diterjemahkan ke dalam tugas dan kewajiban yang tinggi menjalankan atau dedikasi pegawai negeri sipil terhadap profesi, tugas, bangsa dan negara. Diharapkan dalam etos kerja yang ada akan timbul sikap dan perilaku yang produktif didalam melaksanakan pekerjaan dan melayani publik. Berkaitan dengan produktivitas, penulis menemukan beberapa fenomena yang 
berkaitan dengan produktivitas kerja pegawai Dinas Syariat Islam Kabupaten Bener Meriah. Adapun fenomena tersebut ialah terjadinya penurunan produktivitas pada sebagian pegawai yang ada, seperti sering terlambatnya pelaporan, baik berhubungan dengan pelaporan harian, mingguan dan bulanan, pegawai tidak memanfaatkan jam kerja yang ada, banyak diantara pegawai tersebut yang mengisi waktu kerjanya dengan dudukduduk sambil mengobrol ataupun keluar kantor untuk urusan-urusan yang tidak ada kaitannya dengan tugas kerjaan. Hal ini dapat mempengaruhi produktivitas kerja pegawai yang kurang disiplin dan kurang taat pada peraturan yang telah ditetapkan organisasi. Nampak secara empiris di lapangan para pegawai negeri utamanya dilingkungan Dinas Syariat Islam Kabupaten Bener Meriah masih banyak yang menunjukkan produktivitas kerja yang kurang optimal, fenomena lain yakni masih ada pegawai yang melaksanakan tugasnya kurang profesional, seperti kurangnya keterampilan dan kemampuan yang dimiliki pegawai dalam melaksanakan tugas dan pekerjaannyan sehingga pekerjaan menumpuk dan tidak selesai tepat waktu, selain itu pimpinan kurang memberikan pelatihan dan perbaikan kepada pegawainya yang menyebabkan kurangnya pemahaman pegawai tentang pentingnya kerjasama kelompok, koordinasi dan diskusi kelompok.

Dari hasil pengamatan dapat ditemukan etika kerja sebagian pegawai melaporkan bahwa mereka bekerja pas-pasan saja hanya memenuhi persyaratan kerja atau disebut para minimalis. Berdasar latar belakang di atas, dirumuskan tujuan penelitian sebagai berikut : 1) Untuk mengetahui pengaruh kompetensi terhadap produktivitas kerja pegawai di Dinas Syariat Islam Kabupaten bener Meriah. 2) Untuk mengetahui pengaruh iklim organisasi terhadap produktivitas kerja pegawai di Dinas Syariat Islam Kabupaten bener Meriah.

\section{KAJIAN LITERATUR}

Produktivitas kerja merupakan pemanfaatan atau penggunaan sumber dayapegawai secara efektif dan efisien, ketepatan atau keserasian penggunaan metode atau cara kerja dibandingkan dengan alat atau waktu yang tersedia dalam rangka mencapai tujuan. Seorang yang memiliki produktivitas kerja yang tinggi akan memperlihatkan sikap yang positif terhadap pekerjaannya, sedangkan yang tidak puas akan memperlihatkan sikap yang negatif terhadap pekerjaannya itu sendiri.

Konsep produktivitas sangatlah beragam sesuai dengan disiplin ilmu masingmasing. Dari beberapa uraian yang dikemukakan Sedarmayanti, (2001, hal. 57) dikenal beberapa istilah produktivitas, yakni produktivitas kerja pegawai, produktivitas manajer dan produktivitas organisasi. Dalam penelitian ini produktifitas yang dimaksud terfokus pada produktifitas kerja pegawai. Pegawai atau tenaga kerja disini merupakan hal yang dominan sekali dalam setiap upaya peningkatan produktifitas, karena alat produksi dan teknologi pada hakekatnya merupakan hasil karya manusia. Namun, masalah yang timbul pada saat pegawai dari organisasi yang sebenarnya memiliki potensi yang baik untuk mengerjakan tugas dan wewenang yang diberikan kepadanya tetapi tidak melaksanakan tugas tersebut dengan baik dikarenakan banyak factor yang mempengaruhinya.

\section{METODE}

Pendekatan ini berpendekatan kuantitatif, berjenis deskriftif dan asosiatif. Dikatakan pendekatan kuantitatif sebab pendekatan yang digunakan di dalam usulan penelitian, proses, hipotesis, turun ke lapangan, analisa data dan kesimpulan data sampai dengan penulisannya menggunakan aspek pengukuran, perhitungan, rumus dan kepastian data numerik. Menurut Juliandi dan Irfan (2014: 89), mengatakan : "Analisis data 
deskriftif berarti menganalisa data untuk permasalahan variabel - variabel mandiri “. Sedangkan "Analisis data asosiatif bertujuan menganalisis permasalahan hubungan suatu variabel dengan variabel lainnya".

Defenisi operasional dari variabel - variabel yang kan diteliti adalah :

Variabel Dependen (Y)

Variabel dependen dalam penelitian ini adalah Produktivitas Kerja. Menurut Hasibuan (2005: 126) Produktivitas adalah perbandingan antara output (hasil) dengan input (masukan). Jika Produktivitas naik ini hanya dimungkinkan oleh adanya peningkatan efisiensi (waktu-bahan-tenaga) dan sisitem kerja, teknik produksi dan adanya peningkatan keterampilan dari tenaga kerjanya.

Menurut Umar (2010: 11) menjelaskan ada enam faktor utama yang menentukan indikator produktivitas kerja yaitu : (1) Sikap Kerja, (2) Tingkat keterampilan, (3) Hubungan antara tenaga kerja dan pimpinan, (4) Manajemen produktivitas, (5) Efisiensi tenaga kerja dan (6) Kewiraswastaan.

Variabel Independen $(\mathrm{X})$

1. Kompetensi. (X1)

Menurut Wibowo (2007: 86), mengemukakan bahwa : "Kompetensi adalah suatu kemampuan untuk melakukan atau melaksanakan suatu pekerjaan atau tugas yang dilandasi atas keterampilan dan pengetahuan serta didukung oleh sikap kerja yang dituntut oleh pekerjaan tersebut".

Karakteristik kompetensi menurut Menurut Spencer dan Spencer yang dikutip Wibowo (2007: 87), yang kemudian dapat menjadi indikator kompetensi yaitu : (1) Motif (Motives), (2) Sifat (Traits), (3) Konsep diri (Self - concept), (4) Pengetahuan (Knowledge) dan (5) Keterampilan (Skill)

\section{Iklim Organisasi (X2).}

Menurut Wirawan (2007: 121), mengatakan bahwa : "Iklim organisasi merupakan kualitas lingkungan internal organisasi yang secara relatif terus berlangsung, dialami oleh anggota organisasi, mempenagruhi perilaku mereka dan dapat dilukiskan dalam pengertian satun set karakteristik atau sifat organisasi”. Menurut Robert Stringer yang dikutip Wirawan (2007 : 131), indikator - indikator iklim organisasi sebagai berikut : (1) Struktur, (2) Standar - standar, (3) Tanggung jawab, (4) Penghargaan, (5) Dukungan dan (6) Komitmen

\section{Motivasi (X3).}

Motivasi mempersoalkan bagaimana cara organisasi dapat mendorong gairah kerja para pegawai supaya mau bekerja dengan baik untuk memberikan semua kemampuan dan ketrampilannya guna terwujudnya tujuan pegawai itu sendiri maupun tujuan organisasi tempat pegawai tersebut bekerja.

Adapun Indikator - indikator motivasi kerja yang dikembangkan dan dikemukakan oleh Mc. Clelland dalam Hasibuan (2000: 149) sebagai berikut : (1) Motif, (2) Harapan dan (3) Insentif.

Populasi yang diteliti adalah pegawai Dinas Syariat Islam Kabupaten Bener Meriah yang menurut Sugiyono (2008: 72), "Populasi adalah wilayah generalisasi yang terdiri dari; objek/subjek yang mempunyai kualitas dan karakteristik tertentu yang ditetapkan oleh peneliti untuk dipelajari dan kemudian ditarik kesimpulannya". Adapun yang menjadi populasi pada penelitian ini adalah seluruh pegawai negeri sipil Dinas Syariat Islam Kabupaten Bener meriah yang berjumlah 44 orang. 
Tabel 1.

Jumlah Pegawai Pada Dinas Syariat Islam Kabupaten Bener Meriah

\begin{tabular}{|c|l|c|}
\hline No & \multicolumn{1}{|c|}{ Jabatan } & Jumlah Pegawai \\
\hline & $\begin{array}{r}\text { Sekretaris, membawahi : } \\
-\quad \text { Sub Bagian Umum }\end{array}$ & \\
1 & $-\quad$ Sub Bagian Kepegawaian & 15 Orang \\
& $-\quad$ Sub Bagian Keuangan & 6 Orang \\
\hline 2 & Bidang Program dan Pelaporan & 7 Orang \\
\hline 3 & Bidang Bina Hukum Syariat Islam & 8 Orang \\
\hline 4 & Bidang Dakwah Peribadatan & 8 Orang \\
\hline 5 & Bidang SDM & 44 Orang \\
\hline 6 & Total \\
\hline
\end{tabular}

Sumber: Dinas Syariat Islam Kabupaten Bener meriah (2016)

Sampel Menurut Sugiyono (2007: 73), Sampel adalah bagian dari jumlah dan karakteristik yang dimiliki oleh populasi tersebut. Penelitian ini menggunakan teknik pengambilan sampel yaitu sampling jenuh adalah teknik penentuan sampel apabila semua anggota populasi digunakan sebagai sampel Sugiyono (2007: 78), sampel pada penelitian ini berjumlah 44 orang. Untuk mengumpulkan data yang diperlukan dalam peenelitian ini adalah Data primer adalah data yang diperoleh langsung dari lapangan atau data yang bersumber dari informan dan pengamatan langsung di lokasi penelitian dan Kuesioner Yakni pengumpulan data dengan membuat daftar pertanyaan dalam bentuk angket yang diberikan kepada responden.

\section{HASIL DAN DISKUSI}

\section{Statistik Deskriptif}

Tabel 2.

Frekuensi jawaban responden untuk variabel bebas Kompetensi $\left(\mathbf{X}_{1}\right)$

\begin{tabular}{|l|l|l|l|l|l|l|l|l|l|l|l|l|l|l|}
\hline \multirow{2}{*}{ No } & Item & SS & S & \multicolumn{3}{l}{ KS } & \multicolumn{3}{l|}{ TS } & \multicolumn{3}{l|}{ STS } & \multicolumn{2}{l|}{ Jumlah } \\
\cline { 3 - 12 } & Pernyataan & $\mathbf{F}$ & $\mathbf{\%}$ & $\mathbf{F}$ & $\mathbf{\%}$ & $\mathbf{F}$ & $\mathbf{\%}$ & $\mathbf{F}$ & $\mathbf{\%}$ & $\mathbf{F}$ & $\mathbf{\%}$ & $\mathbf{F}$ & $\mathbf{\%}$ \\
\hline 1 & Pernyataan 1 & 13 & 29.5 & 31 & 70.5 & 0 & 0 & 0 & 0 & 0 & 0 & 44 & 100 \\
\hline 2 & Pernyataan 2 & 12 & 27.3 & 31 & 70.5 & 1 & 2.3 & 0 & 0 & 0 & 0 & 44 & 100 \\
\hline 3 & Pernyataan 3 & 14 & 31.8 & 27 & 61.4 & 3 & 6.8 & 0 & 0 & 0 & 0 & 44 & 100 \\
\hline 4 & Pernyataan 4 & 5 & 11.4 & 34 & 77.3 & 5 & 11.4 & 0 & 0 & 0 & 0 & 44 & 100 \\
\hline 5 & Pernyataan 5 & 8 & 18.2 & 31 & 70.5 & 5 & 11.4 & 0 & 0 & 0 & 0 & 44 & 100 \\
\hline 6 & Pernyataan 6 & 8 & 18.2 & 36 & 81.8 & 0 & 0 & 0 & 0 & 0 & 0 & 44 & 100 \\
\hline 7 & Pernyataan 7 & 5 & 11.4 & 27 & 61.4 & 12 & 27.3 & 0 & 0 & 0 & 0 & 44 & 100 \\
\hline 8 & Pernyataan 8 & 10 & 22.7 & 26 & 63.6 & 6 & 13.6 & 0 & 0 & 0 & 0 & 44 & 100 \\
\hline 9 & Pernyataan 9 & 5 & 11.4 & 38 & 86.4 & 1 & 2.3 & 0 & 0 & 0 & 0 & 44 & 100 \\
\hline 10 & Pernyataan 10 & 11 & 25.0 & 32 & 72.7 & 1 & 2.3 & 0 & 0 & 0 & 0 & 44 & 100 \\
\hline 11 & Pernyataan 11 & 0 & 0 & 35 & 79.5 & 9 & 20.5 & 0 & 0 & 0 & 0 & 44 & 100 \\
\hline 12 & Pernyataan 12 & 6 & 13.6 & 27 & 61.4 & 11 & 25.0 & 0 & 0 & 0 & 0 & 44 & 100 \\
\hline 13 & Pernyataan 13 & 4 & 9.1 & 28 & 63.6 & 12 & 27.3 & 0 & 0 & 0 & 0 & 44 & 100 \\
\hline 14 & Pernyataan 14 & 6 & 13.6 & 35 & 79.5 & 3 & 6.8 & 0 & 0 & 0 & 0 & 44 & 100 \\
\hline 15 & Pernyataan 15 & 9 & 20.5 & 34 & 77.3 & 1 & 2.3 & 0 & 0 & 0 & 0 & 44 & 100 \\
\hline
\end{tabular}




\begin{tabular}{|l|l|l|l|l|l|l|l|l|l|l|l|l|l|}
\hline & Total & 116 & & 472 & & 70 & & 0 & & 0 & & 660 & \\
\hline
\end{tabular}

Berdasarkan tabel 2 untuk daftar pertanyaan variabel jawaban responden kompetensi berada pada jawaban sangat setuju, setuju, kurang setuju dengan kriteria jawaban sangat setuju sebanyak $17.6 \%$, sebanyak $71.5 \%$ untuk jawaban setuju, serta sebanyak $10.6 \%$ untuk jawaban kurang setuju.

Hal ini menunjukkan secara umum, kompetensi di Dinas Syariat Islam Kabupaten Bener Meriah sudah termasuk baik. Namun masih ada beberapa masalah yang perlu diperbaiki pada pernyataan kesebelas "Saya selalu mempelajari dan meningkatkan pengetahuan saya tentang standar prosedur pelayanan terhadap pekerjaan saya dan melakukannya sesuai dengan yang saya pelajari dengan baik dan benar" sebanyak $20.5 \%$, menjawab kurang setuju. Pada pernyataan keduabelas "Saya melakukan pekerjaan administrasi dengan baik dan benar", sebanyak 25.0\%, menjawab kurang setuju. Kemudian juga pada pernyataan ketigabelas "Saya melakukan pekerjaan saya dengan selalu memanajemenkannya atau melakukan pengaturan secara teratur dan sistematis" sebanyak $27.3 \%$, menjawab kurang setuju.

Tabel 3.

Frekuensi jawaban responden untuk variabel bebas Iklim Organisasi $\left(\mathrm{X}_{2}\right)$

\begin{tabular}{|c|c|c|c|c|c|c|c|c|c|c|c|c|c|c|}
\hline \multirow{2}{*}{ No } & \multirow{2}{*}{$\begin{array}{c}\text { Item } \\
\text { Pernyataan }\end{array}$} & \multicolumn{2}{|c|}{ SS } & \multicolumn{3}{|c|}{ S } & \multicolumn{2}{|c|}{ KS } & \multicolumn{2}{|c|}{ TS } & \multicolumn{2}{|c|}{ STS } & \multicolumn{2}{c|}{ Jumlah } \\
\cline { 3 - 15 } & Pernyataan 1 & 4 & 9.1 & 39 & 88.6 & 1 & 2.3 & 0 & 0 & 0 & 0 & 44 & 100 \\
\hline 1 & Pernyataan 2 & 4 & 9.1 & 39 & 88.6 & 1 & 2.3 & 0 & 0 & 0 & 0 & 44 & 100 \\
\hline 2 & Pernyataan 3 & 9 & 20.5 & 34 & 77.3 & 1 & 2.3 & 0 & 0 & 0 & 0 & 44 & 100 \\
\hline 3 & Pernyataan 4 & 2 & 4.5 & 31 & 70.5 & 11 & 25.0 & 0 & 0 & 0 & 0 & 44 & 100 \\
\hline 4 & Pernyataan 5 & 2 & 4.5 & 21 & 47.7 & 20 & 45.5 & 1 & 2. & 0 & 0 & 44 & 100 \\
\hline 5 & Total & 21 & & 164 & & 34 & & 1 & & 0 & & 220 & \\
\hline
\end{tabular}

Berdasarkan tabel 3 untuk daftar pertanyaan variabel jawaban responden iklim organisasi berada pada jawaban sangat setuju, setuju, kurang setuju dan tidak setuju dengan kriteria jawaban sangat setuju sebanyak 9,5\%, sebanyak $74.5 \%$ untuk jawaban setuju, sebanyak $15.5 \%$ untuk jawaban kurang setuju, selanjutnya sebanyak $2.3 \%$ untuk jawaban tidak setuju.

Hal ini menunjukkan secara umum, iklim organisasi di Dinas Syariat Islam Kabupaten Bener Meriah sudah termasuk baik. Namun masih ada beberapa masalah yang perlu diperbaiki pada pernyataan keempat " Penghargaan selalu diberikan kepada pegawai yang berprestasi baik dalam sanjuingan maupun dalam bentuk prestasi kinerja" sebanyak $20.5 \%$, menjawab kurang setuju. Pada pernyataan kelima "Pekerjaan yang saya lakukan selalu mendapat dukungan dari atasan maupun tempat kerja" sebanyak 45.5\% menjawab kurang setuju dan sebanyak $2.3 \%$ mnjawab tidak setuju. 
Tabel 4.

Frekuensi jawaban responden untuk variabel bebas Motivasi $\left(\mathrm{X}_{3}\right)$

\begin{tabular}{|c|c|c|c|c|c|c|c|c|c|c|c|c|c|c|}
\hline \multirow{2}{*}{ No } & \multirow{2}{*}{$\begin{array}{c}\text { Item } \\
\text { Pernyataan }\end{array}$} & $\mathbf{F}$ & \multicolumn{3}{|c|}{ S } & \multicolumn{2}{|c|}{ KS } & \multicolumn{2}{|c|}{ TS } & \multicolumn{2}{|c|}{ STS } & \multicolumn{2}{|c|}{ Jumlah } \\
\hline & F & $\mathbf{\%}$ & $\mathbf{F}$ & $\mathbf{\%}$ & $\mathbf{F}$ & $\mathbf{\%}$ & $\mathbf{F}$ & $\mathbf{\%}$ & $\mathbf{F}$ & $\mathbf{\%}$ & $\mathbf{F}$ & $\mathbf{\%}$ \\
\hline 1 & Pernyataan 1 & 5 & 11.4 & 34 & 77.3 & 5 & 11.4 & 0 & 0 & 0 & 0 & 44 & 100 \\
\hline 2 & Pernyataan 2 & 0 & 0 & 42 & 95.5 & 2 & 4.5 & 0 & 0 & 0 & 0 & 44 & 100 \\
\hline 3 & Pernyataan 3 & 0 & 0 & 41 & 93.2 & 3 & 6.8 & 0 & 0 & 0 & 0 & 44 & 100 \\
\hline 4 & Pernyataan 4 & 5 & 11.4 & 38 & 86.4 & 1 & 2.3 & 0 & 0 & 0 & 0 & 44 & 100 \\
\hline 5 & Pernyataan 5 & 5 & 11.4 & 34 & 77.3 & 5 & 11.4 & 0 & 0 & 0 & 0 & 44 & 100 \\
\hline 6 & Pernyataan 6 & 3 & 6.8 & 40 & 90.9 & 1 & 2.3 & 0 & 0 & 0 & 0 & 44 & 100 \\
\hline 7 & Pernyataan 7 & 8 & 18.2 & 32 & 72.7 & 4 & 9.1 & 0 & 0 & 0 & 0 & 44 & 100 \\
\hline 8 & Pernyataan 8 & 4 & 9.1 & 34 & 77.3 & 6 & 13.6 & 0 & 0 & 0 & 0 & 44 & 100 \\
\hline 9 & Pernyataan 9 & 19 & 43.2 & 19 & 43.2 & 6 & 13.6 & 0 & 0 & 0 & 0 & 44 & 100 \\
\hline 10 & Pernyataan 10 & 4 & 9.1 & 34 & 77.3 & 6 & 13.6 & 0 & 0 & 0 & 0 & 44 & 100 \\
\hline 11 & Pernyataan 11 & 3 & 6.8 & 33 & 75.0 & 8 & 18.2 & 0 & 0 & 0 & 0 & 44 & 100 \\
\hline 12 & Pernyataan 12 & 2 & 4.5 & 37 & 84.1 & 5 & 11.4 & 0 & 0 & 0 & 0 & 44 & 100 \\
\hline 13 & Pernyataan 13 & 1 & 2.3 & 39 & 88.6 & 4 & 9.1 & 0 & 0 & 0 & 0 & 44 & 100 \\
\hline 14 & Pernyataan 14 & 7 & 15.9 & 31 & 70.5 & 6 & 13.6 & 0 & 0 & 0 & 0 & 44 & 100 \\
\hline 15 & Pernyataan 15 & 8 & 18.2 & 35 & 79.5 & 1 & 2.3 & 0 & 0 & 0 & 0 & 44 & 100 \\
\hline 16 & Pernyataan 16 & 5 & 11.4 & 32 & 72.7 & 7 & 15.9 & 0 & 0 & 0 & 0 & 44 & 100 \\
\hline & Total & 79 & & 555 & & 66 & & 0 & & 0 & & 704 & \\
\hline
\end{tabular}

Berdasarkan tabel 4 untuk daftar pertanyaan variabel jawaban responden motivasi berada pada jawaban sangat setuju, setuju dan kurang setuju dengan kriteria jawaban sangat setuju sebanyak $11.2 \%$, sebanyak $78.8 \%$ untuk jawaban setuju, serta $9.4 \%$ untuk jawaban kurang setuju.

Hal ini menunjukkan secara umu, motivasi di Dinas Syariat Islam Kabupaten Bener Meriah sudah termasuk baik. Namun masih ada beberapa masalah yang perlu diperbaiki pada pernyataan kelima "Suasana di dalam tempat saya bekerja selalu terasa nyaman", sebanyak $11.4 \%$, menjawab kurang setuju. Pada pernyataan kedelapan “ Prestasi yang saya lakukan dalam melakukan pekerjaan selalu diakui dan dihargai oleh atasan", sebanyak $13.6 \%$, menjawab kurang setuju.

Kemudian juga pada pernyataan kesebelas "Pimpinan di tempat saya bekerja selalu melakukan pendisplinan bawahannya secara bijaksana",sebanyak $18.2 \%$, menjawab kurang setuju. Selanjutnya pada pernyataan keempatbelas " persoalan persoalan pribadi pegawai yang ada selalu dipahami dan dimengerti secara profesional dan tidak saling mengganggu antara sesama pegawai", sebanyak 13.6\%, menjawab kurang setuju. 
Tabel 5.

Frekuensi jawaban responden untuk variabel bebas Produktiitas Kerja (Y)

\begin{tabular}{|c|c|c|c|c|c|c|c|c|c|c|c|c|c|}
\hline \multirow[t]{2}{*}{ No } & \multirow{2}{*}{$\begin{array}{c}\text { Item } \\
\text { Pernyataan }\end{array}$} & \multicolumn{2}{|l|}{ SS } & \multicolumn{2}{|l|}{$\mathbf{S}$} & \multicolumn{2}{|c|}{$\mathbf{K S}$} & \multicolumn{2}{|c|}{ TS } & \multicolumn{2}{|c|}{ STS } & \multicolumn{2}{|c|}{ Jumlah } \\
\hline & & $\mathbf{F}$ & $\%$ & $\mathbf{F}$ & $\%$ & $\mathbf{F}$ & $\%$ & $\mathbf{F}$ & $\%$ & $\mathbf{F}$ & $\%$ & $\mathbf{F}$ & $\%$ \\
\hline 1 & Pernyataan 1 & 7 & 15.9 & 37 & 84.1 & 0 & 0 & 0 & 0 & 0 & 0 & 44 & 100 \\
\hline 2 & Pernyataan 2 & 0 & 0 & 43 & 97.7 & 1 & $\begin{array}{l}2 . \\
3\end{array}$ & 0 & 0 & 0 & 0 & 44 & 100 \\
\hline 3 & Pernyataan 3 & 1 & 2.3 & 32 & 72.7 & 0 & 0 & 0 & 0 & 0 & 0 & 44 & 100 \\
\hline 4 & Pernyataan 4 & 2 & 4.5 & 40 & 90.9 & 2 & $\begin{array}{l}4 . \\
5\end{array}$ & 0 & 0 & 0 & 0 & 44 & 100 \\
\hline 5 & Pernyataan 5 & 2 & 4.5 & 42 & 95.5 & 0 & 0 & 0 & 0 & 0 & 0 & 44 & 100 \\
\hline 6 & Pernyataan 6 & 1 & 2.3 & 21 & 47.7 & 22 & $\begin{array}{l}50 . \\
0\end{array}$ & 0 & 0 & 0 & 0 & 44 & 100 \\
\hline & Total & 13 & 29.5 & 179 & & 25 & & 0 & 0 & 0 & 0 & 264 & 100 \\
\hline
\end{tabular}

Berdasarkan tabel 5 untuk daftar perntanyaan variabel jawaban responden produktivitas kerja berada pada jawaban sangat setuju, setuju dan kurang setuju dengan kriteria jawaban sangat setuju sebanyak $4.9 \%$, sebanyak $67.8 \%$ untuk jawaban setuju, sebanyak $9.5 \%$ untuk jawaban kurang setuju.

Hal ini menunjukkan secara umum, produktivitas kerja di Dinas Syariat Islam sudah termasuk baik. Namun masih ada beberapa masalah yang perlu diperbaiki pada pernyataan kedua "Saya terus meningkatkan keterampilan pekerjaan saya dalam melakukan pekerjaan sehari - hari”, sebanyak 2.3\%, menjawab kurang setuju. Pada pernyataan keempat "Saya merasa pengaturan pekerjaan telah dilakukan oleh atasan dengan baik sehingga dapat meningkatkan produktivitas pekerjaan saya", sebanyak $4.5 \%$, menjawab kurang setuju. Selanjutnya pada pernyataan keenam "Saya selalu diberikan inisiatif dan kebebasan dalam pekerjaan saya sehingga dapat meningkatkan produktiitas kerja saya", sebanyak $50.0 \%$, menjawab kurang setuju.

\section{Uji Asumsi Klasik}

Uji asumsi klasik digunakan untuk melihat atau menguji apakah suatu model layak atau tidak layak digunakan dalam penelitian. Uji asumsi klasik yang digunakan dalam penelitian ini adalah :

\section{a. Uji Normalitas}

Uji normalitas data bertujuan untuk menguji apakah dalam model regresi antara variabel bebas dan variabel terikat mempunyai distribusi normal atau tidak dengan menggunakan uji kolmogorof smirnov test. Seperti pada gambar 4.1 yaitu :

Tabel 6. One-Sample Kolmogorov-Smirnov Test

\begin{tabular}{|ll|r|}
\hline & & \multicolumn{2}{|c|}{ Unstandardized Residual } \\
\hline $\mathrm{N}$ & Mean & 44 \\
Normal Parameters ${ }^{\mathrm{a}, \mathrm{b}}$ & Std. Deviation & .0000000 \\
& Absolute & .68423330 \\
& .096 \\
Most Extreme Differences & Positive & .067 \\
& Negative & -.096 \\
Kolmogorov-Smirnov Z & & 634 \\
Asymp. Sig. (2-tailed) & & .816 \\
\hline
\end{tabular}

a. Test distribution is Normal.

b. Calculated from data. 
- Terlihat pada tabel bahwa nilai Asymp.Sig. (2-tailed) adalah 0,816 dan diatas nilai signifikan $(0,05)$ dengan kata lain variabel residual berdistribusi dengan normal

- Nilai kolmogorov-sminov Z lebih kecil dari 1,97 yaitu 0,634 yang berarti tidak ada perbedaan antara distribusi teoritik dan distribusi empiric tau dengan kata lain data dikatakan normal

\section{b. Uji Multikolonieritas}

Uji multikolonieritas dilakukan untuk melihat apakah pada model regresi linier berganda ditemukan adanya korelasi antara variabel bebas. Model regresi yang baik seharusnya tidak terjadi multikolonieritas. Untuk uji multikolonieritas pada penelitian ini adalah dengan melihat nilai Variance Inflation Factor (VIF).

Tabel 7.

Hasil Uji Multikolonieritas

\begin{tabular}{|ll|r|r|}
\hline \multirow{2}{*}{ Model } & \multicolumn{2}{|c|}{ Collinearity Statistics } \\
\cline { 3 - 4 } & Tolerance & \multicolumn{2}{|c|}{ VIF } \\
\hline 1 & (Constant) & .298 & \\
& X1 & .299 & 3.359 \\
X2 & .956 & 3.346 \\
& X3 & .956 & 1.046 \\
\hline
\end{tabular}

a. Dependent Variable: $Y$

Dari tabel 7 di atas menunjukkan bahwa nilai Tolerance $>0,10$ yang berarti tidak ada korelasi antar variabel independen. Hasil perhitungan nilai Variance Inflation Factor (VIF) juga menunjukkan hal yang sama tidak ada satu variabel independen yang memiliki nilai VIF lebih dari 10. Jadi dapat disimpulkan bahwa tidak ada multikolonieritas antar variabel independen dalam model regresi pada penelitian ini.

\section{c. Uji Heteroskedastisitas}

Metode ini digunakan untuk menguji apakah dalam sebuah model regresi terjadi kesamaan varians dari residual pada satu pengamatan ke pengamatan lainnya. Jika varians dari satu residual suatu pengamatan ke pengamatan lainnya tetap, maka terjadi homoskedastisitas namun jika varians berbeda, maka disebut heteroskedastisitas. Model regresi yang baik adalah yang tidak terjadi heteroskedastisitas. "Untuk mengetahui ada tidaknya gejala heteroskedastisitas adalah dengan melihat ada tidaknya pola tertentu pada grafik Scatterplot, jika ada pola tertentu maka telah terjadi heteroskedastisitas pada model regresi" (Situmorang et al., 2010:100).

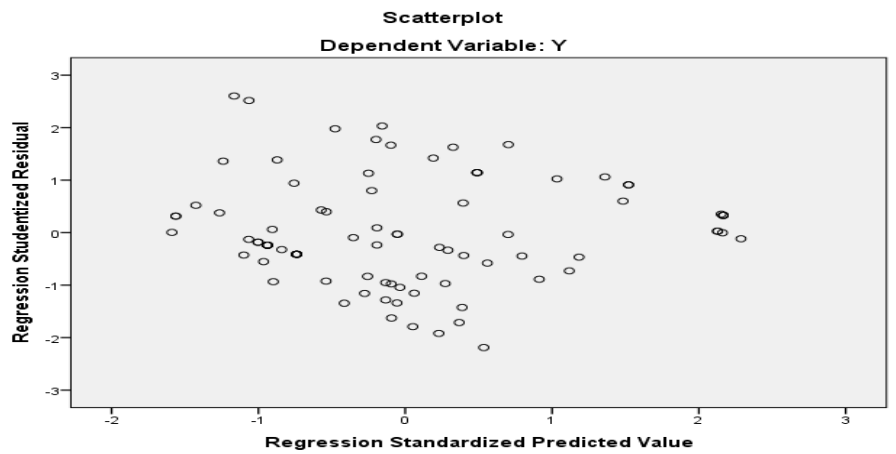

Gambar 1. Scatterplot Uji Heteroskedastisitas 
Pada Gambar 1 grafik scatterplot terlihat titik-titik menyebar secara acak dan tidak membentuk sebuah pola tertentu yang jelas, serta tersebar baik di atas maupun dibawah angka 0 pada sumbu Y. Hal ini berarti tidak terjadi heteroskedastisitas pada model regresi, sehingga model regresi layak dipakai untuk memprediksi Produktivitas Kerja berdasarkan masukan variabel Kompetensi, Iklim Organisasi dan Motivasi.

\section{Model Regresi Linier Berganda}

Model regresi linier berganda dilakukan untuk mengetahui besar pengaruh variabel bebas (Kompetensi, Iklim Organisasi, Motivasi) terhadap variabel terikat (Produktivitas Kerja).Berdasarkan pengujian menggunakan program SPSS Statistics 19.0 for windows, maka hasil persamaan regresi linear berganda penelitian dapat dilihat pada Tabel 8 .

Tabel 8.

Koefesien Regresi Berganda

\begin{tabular}{|c|c|c|c|c|c|}
\hline \multirow[t]{2}{*}{ Model } & \multicolumn{2}{|c|}{$\begin{array}{c}\text { Unstandardized } \\
\text { Coefficients } \\
\end{array}$} & \multirow{2}{*}{$\begin{array}{c}\begin{array}{c}\text { Standardized } \\
\text { Coefficients }\end{array} \\
\text { Beta } \\
\end{array}$} & \multirow[t]{2}{*}{$\mathbf{t}$} & \multirow[t]{2}{*}{ Sig. } \\
\hline & B & Std. Error & & & \\
\hline \multirow{4}{*}{$\begin{array}{l}\text { (Constant) } \\
\text { X1 } \\
\text { X2 } \\
\text { X3 }\end{array}$} & 5.079 & 1.671 & & 3.040 & .004 \\
\hline & .091 & .034 & .286 & 2.678 & .011 \\
\hline & .190 & .084 & .251 & 2.255 & .030 \\
\hline & .142 & .035 & .456 & 4.031 & .000 \\
\hline
\end{tabular}

\section{a. Dependent Variable: Y}

Berdasarkan tabel 4.11, model persamaan regresi linear berganda dalam persamaan ini adalah :

$$
Y=5.079+0.91 X_{1}+190 X_{2}+142 X_{3}+e
$$

Berdasarkan persamaan tersebut dapat di uraikan sebagai berikut:

a. Konstanta bernilai 5.079 menunjukkan ba hwa jika tidak ada pengaruh dari variabel kompetensi, iklim organisasi, dan motivasi $\left(\mathrm{X}_{1}, \mathrm{X}_{2}, \mathrm{X}_{3}\right)$ maka Produktivitas kerja (Y) akan tetap ada sebesar 5.079.

b. Koefisien Kompetensi $\left(\beta_{1}\right)=0.091$, ini menunjukkan setiap terjadi peningkatan variabel kompetensi sebesar satu satuan maka akan meningkatkan produktivitas kerja sebesar 0.091 .

c. Koefisien Iklim Organisasi $\left(\beta_{2}\right)=0.190$, ini menunjukkan setiap terjadi peningkatan variabel iklim organisasi sebesar satu satuan maka akan meningkatkan produktivitas kerja sebesar 0.190 .

d. Koefisien $X_{3}\left(\beta_{3}\right)=0.142$, ini menunjukkan setiap terjadi peningkatan variabel motivasi sebesar satu satuan maka akan meningkatkan produktivitas kerja sebesar 0.142 .

\section{Uji Hipotesis}

a. Uji Secara Parsial (Uji-t)

Uji t (parsial) dilakukan untuk melihat secara individu pengaruh dari variabel bebas $\left(\mathrm{X}_{1}, \mathrm{X}_{2}, \mathrm{X}_{3}\right)$ berupa kompetensi, iklim organisasi dan motivasi secara parsial berpengaruh positif dan signifikan terhadap produktivitas kerja pegawai Dinas Syariat Islam Kabupaten Bener Meriah.

Tahap - tahap : 
1) Bentuk Pengujian

$\mathrm{H}_{0}: \mathrm{r}_{\mathrm{s}}=0$, artinya tidak terdapat hubungan signifikan antara variabel bebas (X) dengan variabel terikat $(\mathrm{Y})$.

$\mathrm{H}_{0}: \mathrm{r}_{\mathrm{s}} \neq 0$, artinya terdapat hubungan signifikan antara variabel bebas $(\mathrm{X})$ dengan variabel terikat $(\mathrm{Y})$.

2) Kriteria Pengambilan Keputusan

$\mathrm{H}_{0}$ diterima jika $-\mathrm{t}_{\text {tabel }} \leq$ hitung $\leq \mathrm{t}_{\text {tabel, }}$ pada $\alpha=5 \%$, df $=\mathrm{n}-2$

$\mathrm{H}_{0}$ ditolak jika :

a. $t_{\text {hitung }}>t_{\text {tabel }}$

b. - $t_{\text {hitung }}<-t_{\text {tabel }}$

$\mathrm{n}=$ jumlah sampel, $\mathrm{n}=44$

$\mathrm{k}=$ jumlah variabel yang digunakan, $\mathrm{k}=3$

Maka: derajat bebas $=\mathrm{n}-\mathrm{k}=44-3=41$ 2,020 .

Uji $t$ hitung yang dilakukan adalah uji dua arah, maka $t_{\text {tabel }}$ yang digunakan $t$ tabel $=$

Hasil pengujian Uji t (uji parsial) menggunakan program SPSS Statistics 20.0 for windows dapat terlihat pada Tabel 4.12 yaitu :

Tabel 9.

Uji t

\begin{tabular}{|l|r|r|r|r|r|}
\hline Model & \multicolumn{2}{|c|}{$\begin{array}{c}\text { Unstandardized } \\
\text { Coefficients }\end{array}$} & $\begin{array}{c}\text { Standardized } \\
\text { Coefficients }\end{array}$ & \multirow{2}{*}{ T } & \multirow{2}{*}{ Sig. } \\
\cline { 2 - 5 } & \multicolumn{1}{|c|}{ B } & Std. Error & \multicolumn{1}{c|}{ Beta } & & \\
\hline \multirow{4}{*}{ (Constant) } & 5.079 & 1.671 & & 3.040 & .004 \\
X1 & .091 & .034 & .286 & 2.678 & .011 \\
X2 & .190 & .084 & .251 & 2.255 & .030 \\
X3 & .142 & .035 & .456 & 4.031 & .000 \\
\hline
\end{tabular}

a. Dependent Variable: Y

Hasil pengujian statistic pada tabel 9 dapat dijelaskan sebagai berikut :

a. Nilai $t_{\text {hitung }}$ variabel kompetensi adalah 2.678 dan $\mathrm{t}$ tabel 2.020 sehingga $\mathrm{t}_{\text {hitung }} 2.678>\mathrm{t}_{\text {tabel }} 2.020$, dan signifikan $(\mathrm{Sig})<5 \%(0.011<0,05)$ artinya $\mathrm{H}_{0}$ ditolak. Sehingga dapat disimpulkan bahwa kompetensi berpengaruh positif dan signifikan terhadap produktivitas kerja di Dinas Syariat Islam Kabupaten Bener Meriah.

Seperti pada gambar 2 Kurva Uji t variabel Kompetensi (X1)

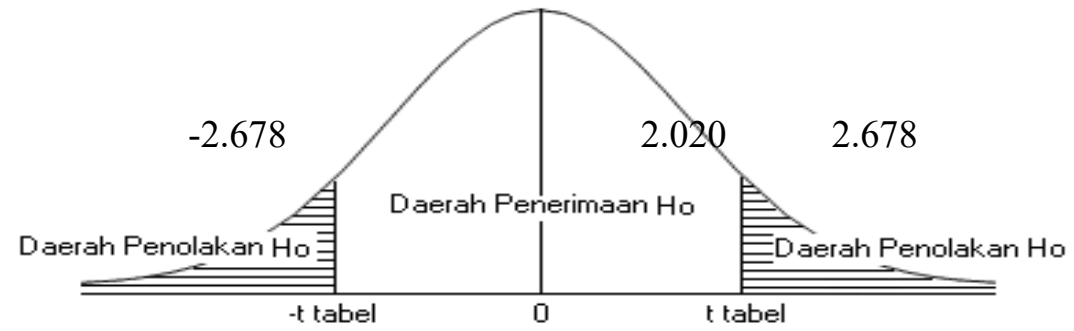

Gambar 2. Kurva Uji t pada variabel kompetensi 
b. Nilai $t_{\text {hitung }}$ variabel iklim organisasi adalah 2.255 dan $t$ tabel 2.020 sehingga $t_{\text {hitung }}$ $>\mathrm{t}_{\text {tabel }}(2.255<2.020)$ dan signifikan $(\mathrm{Sig})<5 \% \quad(0.030<0.05)$ artinya $\mathrm{h} 0$ diterima. Sehingga dapat disimpulkan bahwa variabel iklim organisasi berpengaruh positif dan berpengaruh signifikan terhadap produktivitas kerja pegawai Dinas Syariat Islam Kabupaten Bener Meriah.

Seperti pada gambar 3 Kurva Uji t variabel Iklim Organisasi (X2).

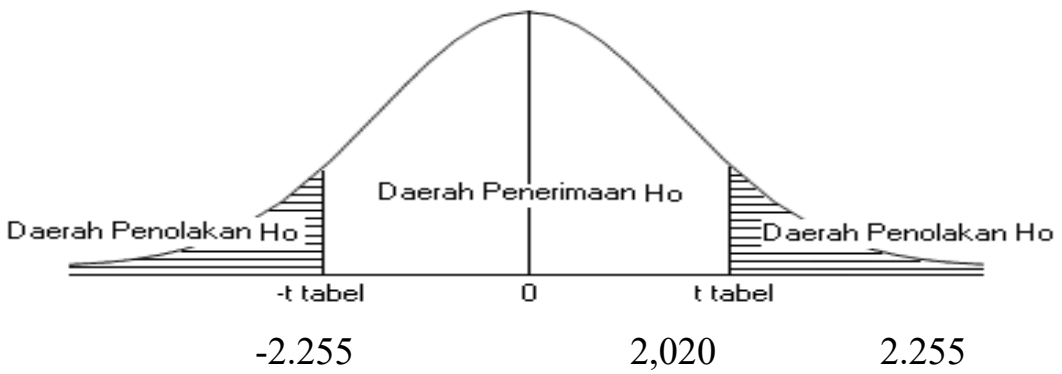

Gambar 3. Kurva Uji t pada variabel iklim organisasi

c. Nilai $t_{\text {hitung }}$ variabel motivasi adalah 4.031 dan $\mathrm{t}$ tabel 2.020 sehingga $t_{\text {hitung }}>t_{\text {tabel }}$ $(4.031<2.020)$ dan signifikan $(\mathrm{Sig})<5 \% \quad(0.000<0.05)$ artinya h0 diterima. Sehingga dapat disimpulkan bahwa variable motivasi berpengaruh positif dan berpengaruh signifikan terhadap produktivitas kerja pegawai Dinas Syariat Islam Kabupaten Bener Meriah.

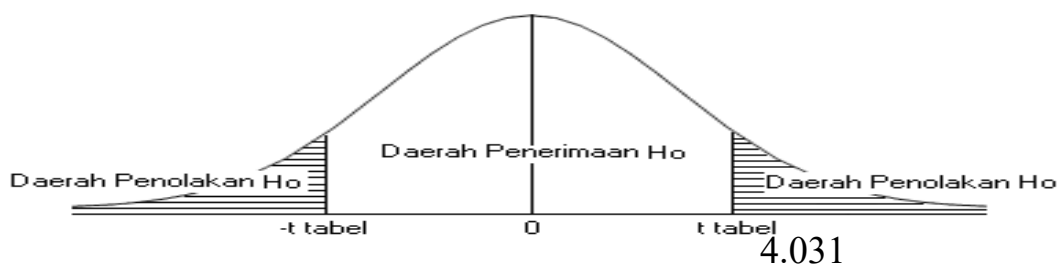

\section{Gambar 4. Kurva Uji t pada variabel Motivasi}

b. Uji Simultan Signifikan(Uji-F)

Uji $\mathrm{F}$ dilakukan untuk melihat secara bersama-sama (serentak) pengaruh dari variable yaitu $\left(\mathrm{X}_{1}, \mathrm{X}_{2}, \mathrm{X}_{3}\right)$ berupa variable kompetensi, iklim organisasi dan motivasi terhadap produktivitas kerja pegawai di Dinas Syariat Islam Kabupaten Bener Meriah. Hipotesis :

Ho : $\beta 1=\beta 2=\beta 3=0$

: Tidak terdapat pengaruh kompetensi, iklim organisasi dan motivasi terhadap produktivitas kerja pegawai Dinas Syariat Islam Kabupaten Bener Meriah.

Ha : $\beta 1 \neq \beta 2 \neq \beta 3 \neq 0$

: Terdapat pengaruh kompetensi, iklim organisasi dan motivasi terhadap produktivitas kerja pegawai Dinas Syariat Islam Kabupaten Bener Meriah. 
Kriteria pengambilan keputusan :

Ho diterima jika $\mathrm{F}_{\text {hitung }}<\mathrm{F}_{\text {tabel }}$ pada $\alpha=5 \%$

Ha diterima jika $F_{\text {hitung }}>F_{\text {tabel }}$ pada $\alpha=5 \%$

Tingkat kesalahan $(\alpha)=5 \%$ dan derajat kebebasan $(\mathrm{df})=(\mathrm{n}-\mathrm{k}) ;(\mathrm{k}-1)$

Derajat bebas pembilang $=\mathrm{k}-1=4-1=3$

Derajat bebas penyebut $=\mathrm{n}-\mathrm{k}=44-4=40$, maka $\mathrm{F}_{\text {tabel }} 0,05(3 ; 40)=2,84$

Tabel 10.

Hasil uji F (anova)

\begin{tabular}{|ll|r|r|r|r|r|}
\hline Model & \multicolumn{1}{|c|}{$\begin{array}{c}\text { Sum of } \\
\text { Squares }\end{array}$} & Df & Mean Square & F & Sig. \\
\hline \multirow{2}{*}{1} & Regression & 58.908 & 3 & 19.636 & 43.470 & $.000^{\mathrm{a}}$ \\
& Residual & 18.069 & 40 & .452 & & \\
& Total & 76.977 & 43 & & & \\
\hline
\end{tabular}

a. Dependent Variable: Y

b. Predictors: (Constant), X3, X2, X1

Berdasarkan Anova (Tabel 10) didapatkan nilai $\mathrm{F}$ hitung sebesar 43.470 dengan tingkat signifikan (Sig.) sebesar 0.000 . Jadi $\mathrm{F}_{\text {hitung }}>\mathrm{F}_{\text {tabel }}(43.470>2,84)$ atau signifikansi (Sig.) $<5 \%(0,000<0,05)$ artinya bahwa variabel kompetensi, iklim organisasi dan motivasi berpengaruh positif dan signifikan terhadap produktivitas kerja.

Jadi dapat disimpulkan H0 ditolak dan Ha diterima. Dengan demikian terdapat pengaruh positif dan signifikan secara bersama - sama kompetensi, iklim organisasi dan motivasi terhadap produktivitas kerja pegawai Dinas Syariat Islam Kabupaten Bener Meriah.

. Kurva uji F seperti yang ditunjukkan pada gamabr 4.7 yaitu :

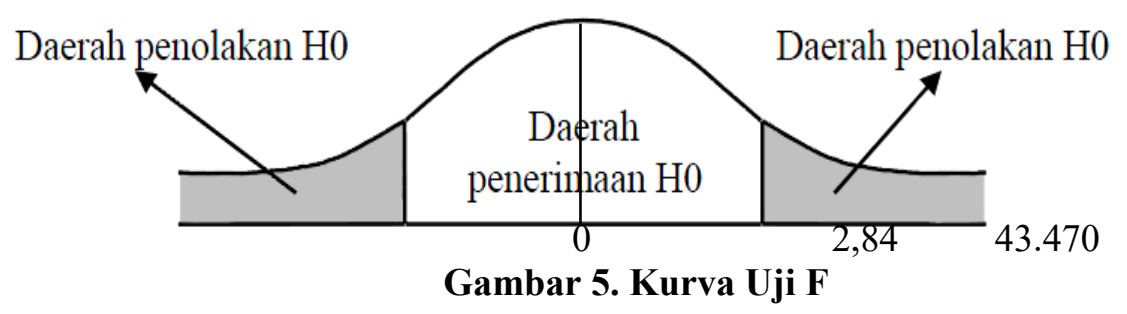

\section{Koefesien Determinasi}

Pengujian Koefisien Determinan digunakan untuk mengukur seberapa besar kontribusi variabel bebas (kompetensi $\left(\mathrm{X}_{1}\right)$, iklim organisasi $\left(\mathrm{X}_{2}\right)$ dan motivasi $\left(\mathrm{X}_{3}\right)$ ) terhadap variabel terikat (produktivitas kerja). Koefisien determinasi berkisar antara nol sampai dengan satu $\left(0<\mathrm{R}^{2}<1\right)$. Jika $\mathrm{R}^{2}$ semakin besar (mendekati satu), maka dapat dikatakan bahwa pengaruh variabel bebas adalah besar terhadap variabel terikat (Y). Sebaliknya, jika $\mathrm{R}^{2}$ semakin kecil (mendekati nol), maka dapat dikatakan bahwa pengaruh variabel bebas adalah kecil terhadap variabel terikat (Y). Hasil pengujian koefisien determinasi terlihat pada tabel 11 yaitu : 
Tabel 11.

Nilai Koefisien Determinasi

\begin{tabular}{|l|r|r|r|r|}
\hline Model & $\mathrm{R}$ & $\mathrm{R}$ Square & $\begin{array}{c}\text { Adjusted R } \\
\text { Square }\end{array}$ & $\begin{array}{c}\text { Std. Error of the } \\
\text { Estimate }\end{array}$ \\
\hline 1 & $.875^{\mathrm{a}}$ & .765 & .748 & 67.210 \\
\hline
\end{tabular}

a.Predictors: (Constant), X3, X2, X1

b.Dependent Variable: Y

Pada tabel diatas, dapat diihat hasil analisis regresi secara keseluruhan menunujukkan nilai Adjusted $\mathrm{R}$ Square $\left(\mathrm{R}^{2}\right)$ sebesar 0.748 menunjukkan bahwa korelasi atau hubungan produktivitas kerja (variabel dependen) dengan kompetensi, iklim organisasi, dan motivasi (variabel independen) mempunyai tingkat hubungan yang kuat yaitu sebesar :

$$
\begin{aligned}
& \mathrm{D}=\mathrm{R}^{2} \times 100 \% \\
& =0.748 \times 100 \% \\
& =74,8 \%
\end{aligned}
$$

Tingkat hubungan yang kuat ini dapat dilihat dari tabel pedoman untuk memberikan interprestasi koefesien korelasi.

Tabel 12.

Pedoman untuk memberikan interprestasi koefesien korelasi.

\begin{tabular}{|c|c|}
\hline Interval Koefesien & Tingkat Hubungan \\
\hline $0,000-0,199$ & Sangat Rendah \\
\hline $0,200-0,399$ & Rendah \\
\hline $0,400-0,599$ & Sedang \\
\hline $0,600-0,799$ & Kuat \\
\hline $0,800-1,000$ & Sangat Kuat \\
\hline
\end{tabular}

Sumber : Sugiyono (2006, hal.183)

Nilai Adjusted $R$ Square $\left(\mathrm{R}^{2}\right)$ atau koefesien determinasi adalah sebesar 74,8 Angka ini mengidentifikasikan bahwa produktivitas kerja (variabel dependen) dengan kompetensi, iklim organisasi, dan motivasi (variabel independen ) sebesar $74.8 \%$, sedangkan selebihnya sebesar $27.2 \%$ dijelaskan oleh sebab - sebab lain yang tidak diteliti dalam penelitian ini. Kemudian standart error of the estimate adalah sebesar 67.210 atau 67.2 dimana semakin kecil angka ini akan membuat model regresi semakin tepat dalam memprediksi produktiitas kerja pegawai.

\section{KESIMPULAN}

Berdasarkan hasil penelitian, maka dapat ditarik beberapa kesimpulan yaitu Kompetensi berpengaruh positif dan signifikan terhadap produktivitas kerja pegawai di Dinas Syariat Islam Kabupaten Bener Meriah. Iklim organisasi berpengaruh positif dan signifikan terhadap produktivitas kerja pegawai di Dinas Syariat Islam Kabupaten Bener Meriah. Motivasi berpengaruh positif dan signifikan terhadap produktivitas terhadap 
produktivitas kerja pegawai di Dinas Syariat Islam Kabupaten Bener Meriah. Kompetensi, iklim organisasidan motivasi secara bersama - sama berpengaruh positif dan signifikan terhadap produktivitas kerja pegawai di Dinas Syariat Islam Kabupaten Bener Meriah.

\section{RFERENSI}

Azuar Juliandi dan Irfan, 2014, Metode Penelitian Kuantitatif, Cetakan Kedua, Bandung : Citapustaka Media Perintis.

Hasibuan, Malayu S.P, 2005. Manajemen Sumber Daya Manusia, Edisi Revisi.Jakarta : Bumi Aksara.

Sugiyono, 2008, Metode Penelitian Bisnis, Cetakan Kesebelas, Bandung: Alpha Beta.

Sedarmayanti, 2001, Produktivitas Kerja Karyawan. Bandung : Bandar Maju.s.

Umar, 2010. Manajemen Sumber Daya Manusia. Prenada Media Group. Jakarta.

Wibowo. 2007. Manajemen Kinerja. Jakarta : PT Raja Grafindo Persada

Wirawan. 2007. Budaya dan Iklim Organisasi : Teori Aplikasi dan Penelitian.

Situmorang Et. Al. 2010. Analisis Data Penelitian; Menggunakan Program SPSS, Terbitan Pertama. Medan. USU Press. 